\title{
Toxicon
}

June 2020, Volume 180, Pages 1-10

https://doi.org/10.1016/i.toxicon.2020.03.007

https://archimer.ifremer.fr/doc/00619/73105/

\section{Health risk assessment related to pinnatoxins in French shellfish}

\author{
Arnich Nathalie 1, 2, 3, ${ }^{*}$, Abadie Eric ${ }^{4}$, Delcourt Nicolas ${ }^{5}$, Fessard Valérie 1, 2, 3, Fremy Jean-Marc 1, 2, 3 , \\ Hort Vincent 1, 2, 3, Lagrange Emmeline ${ }^{6}$, Maignien Thomas 1, 2, 3, Molgó Jordi 7 , \\ Peyrat Marie-Bénédicte ${ }^{1,2,3}$, Vernoux Jean-Paul ${ }^{8}$, Mattei César ${ }^{9}$
}

${ }^{1}$ ANSES (French Agency for Food, Environmental and Occupational Health and Safety), Risk Assessment Directorate, Maisons-Alfort, France

${ }^{2}$ ANSES (French Agency for Food, Environmental and Occupational Health and Safety), Toxicology of Contaminants Unit, Fougères, France

${ }^{3}$ ANSES (French Agency for Food, Environmental and Occupational Health and Safety), Laboratory for Food Safety, Maisons-Alfort, France

${ }^{4}$ IFREMER (French Research Institute for Exploitation of the Sea), Centre for Marine Biodiversity, Exploitation and Conservation (MARBEC), Sète, France

${ }_{5}^{5}$ Poison Control Centre, Toulouse-Purpan University Hospital and Toulouse Neurolmaging Centre (ToNIC), Toulouse, France

${ }^{6}$ Department of Neurology, Reference Center of Neuromuscular Disease, Grenoble University Hospital, France

${ }^{7}$ CEA (French Alternative Energies and Atomic Energy Commission), CNRS, Gif-sur-Yvette, France

8 Normandie University, Caen, France

${ }^{9}$ Mitochondrial and Cardiovascular Pathophysiology, UMR CNRS 6015, INSERM U1083, Angers

University, Angers, France

* Corresponding author : Nathalie Arnich, email address : nathalie.arnich@anses.fr

\begin{abstract}
:
Pinnatoxins (PnTXs) are a group of emerging marine biotoxins produced by the benthic dinoflagellate Vulcanodinium rugosum, currently not regulated in Europe or in any other country in the world. In France, PnTXs were detected for the first time in 2011, in mussels from the Ingril lagoon (South of France, Mediterranean coast). Since then, analyses carried out in mussels from this lagoon have shown high concentrations of PnTXs for several months each year. PnTXs have also been detected, to a lesser extent, in mussels from other Mediterranean lagoons and on the Atlantic and Corsican coasts. In the French data, the main analog is PnTX G (low levels of PnTX A are also present in some samples). No cases of PnTXs poisoning in humans have been reported so far in France or anywhere else in the world. In mice, PnTXs induce acute neurotoxic effects, within a few minutes after oral administration. Clinical signs of toxicity include decreased mobility, paralysis of the hind legs, tremors, jumps and breathing difficulties leading to death by respiratory arrest at high doses. The French agency for food safety (ANSES) recently conducted a review of the state of knowledge related to PnTXs and V. rugosum. Based on (i) the clinical signs of toxicity in mice, (ii) the mode of action of PnTXs as nicotinic acetylcholine receptor competitive antagonists and (iii) knowledge on drugs and natural toxins with PnTX-related pharmacology, potential human symptoms have been extrapolated and proposed. In this work, a provisional acute benchmark value for PnTX G of $0.13 \mu \mathrm{g} / \mathrm{kg}$ bw per day has been derived from an oral
\end{abstract}


acute toxicity study in mice. Based on this value and a large shellfish meat portion size of $400 \mathrm{~g}$, a concentration lower than $23 \mu \mathrm{gnTX} \mathrm{G} / \mathrm{kg}$ shellfish meat is not expected to result in adverse effects in humans. ANSES recommends taking into account PnTXs in the French official monitoring program for shellfish production and identified data gaps to refine health risk assessment.

\section{Highlights}

- A state of knowledge of PnTXs and Vulcanodinium rugosum is proposed. A provisional acute healthbased guidance value for PnTX G of $0.13 \mu \mathrm{g} / \mathrm{kg}$ bw per day has been derived. PnTXs in shellfish should not exceed $23 \mu \mathrm{g} \mathrm{PnTX} \mathrm{G/kg.} \mathrm{PnTXs} \mathrm{should} \mathrm{be} \mathrm{included} \mathrm{in} \mathrm{national} \mathrm{official} \mathrm{monitoring} \mathrm{programs} \mathrm{for}$ shellfish production. This work is a major step forward in taking into account this emerging hazard.

Keywords : Pinnatoxins, Shellfish, Emerging marine biotoxins, Risk assessment 
Pinnatoxins (PnTXs) belong to the group of cyclic imines considered as emerging marine biotoxins (Efsa, 2010a), which, to date, includes 40 compounds, without considering acyl esters produced by shellfish metabolism. This group includes different families determined by their structural characteristics: prorocentrolides, spiroprorocentrimine, gymnodimines (GYMs), spirolides (SPXs), pinnatoxins (PnTXs), pteriatoxins (PtTXs) and portimine. To date, 8 PnTXs (named A to H) have been identified (reviewed by Molgó et al., 2017). PnTXs are soluble in solvents such as acetone, isopropanol and methanol (Zendong et al. 2014). They are amphoteric compounds, i.e. with both acidic and basic properties, which explains their relative water solubility. Due to their lipophilic properties, they can be detected during the mouse bioassay used to screen for lipophilic marine biotoxins.

Vulcanodinium rugosum is the producer of PnTXs identified by Nézan and Chomerat (2011), based on water samples from a Mediterranean lagoon (Ingril, France). V. rugosum also produce portimine (Selwood et al,. 2013; Abadie et al., 2016). This benthic dinoflagellate was a new species belonging to a new genus. No other producer is reported in the literature. The identification of this dinoflagellate in France originates from an atypical situation that occurred in 2006, as part of official monitoring of shellfish production areas. The mouse bioassay used to screen for lipophilic marine biotoxins had revealed unusual neurotoxic effects after the injection of extracts from mussels of the Ingril lagoon. In fact, the symptoms observed for lipophilic toxins are gastrointestinal (diarrhea), and not neurotoxic. Such neurotoxicity could not be related to the presence of regulated marine biotoxins (Amnesic, Paralytic, Diarrhetic toxins) screened for by chemical analysis. In addition, observations of water samples did not conclude to the presence of any microalgae species known to produce neurotoxins. Vulcanodinium rugosum has also been reported in New Zealand (Rhodes et al., 2010), Australia (Rhodes et al., 2011; Munday et al., 2012), Japan (Smith et al., 2011), China Sea (Zeng et al., 2012), Mexico (Hernandez-Becerril et al., 2013), Arabian Gulf (Al Muftah et al., 2016) and Cuba (MoreiraGonzalez et al., 2018).

PnTXs in shellfish are mainly analysed by physico-chemical methods using liquid chromatography coupled with tandem mass spectrometry (LC-MS/MS). Biological (mouse bioassay) or biochemical (functional tests) methods can also be used. None of the methods has yet undergone inter-laboratory 
validation or standardisation. In addition, there are very few standards (reference substances) available for PnTXs, which limits and complicates their detection and quantification. Indeed, to date, only PnTX A and G are marketed as calibration solutions and only PnTX G (Figure 1) has been certified.

Since the first identification of $V$. rugosum in France, high concentrations of PnTXs have been measured in mussels from the Ingril lagoon for several months each year. In 2012, the French Research Institute for Exploitation of the Sea (Ifremer) reported that PnTXs concentrations varied greatly depending on the years (2010, 2011 and 2012), with a maximum of $1244 \mu \mathrm{g}$ of PnTX G per kg of shellfish (wet weight) in 2010 (Ifremer, 2012). However, V. rugosum is rarely detected in water samples collected for the phytoplankton surveillance (in the water column), which can be explained by the benthic nature of this dinoflagellate.

The aims of this work were 1) to review the toxicity data of PnTXs to derive an acute oral health-based guidance value, 2) estimate exposure of shellfish consumers to PnTXs, 3) identify if there might be a public health concern regarding the levels of contamination reported in certain French shellfish production areas, and 4) provide recommendations for the monitoring PnTXs in the marine environment.

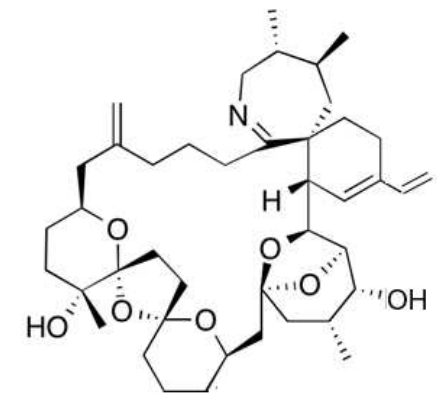

Figure 1: Structure of PnTX G (modified from Araoz et al., 2011).

\section{Vulcanodinium rugosum}

As almost all dinoflagellates, $V$. rugosum (Figure 2) is assumed to have two distinct life phases: a vegetative propagation phase (asexual reproduction) and a sexual phase (Zeng et al., 2012). The asexual phase probably corresponds to the pelagic phase, when the cells are present in the water 


\section{Joumal Pre-proof}

column. The sexual reproduction corresponds to a benthic phase, which could result in the formation of a planozygote that produces a resistance cyst. The pelagic and benthic phases are closely related, but the environmental and/or physiological factors controlling the transition from one phase to the other are not yet known.

The formation of resistance cysts, which can occur at the end of sexual reproduction, is a crucial step for survival in adverse environmental conditions due to chromosomal mixing, which increases intraspecies genetic diversity. Cysts are also one of the ways in which the species spreads, through the transfer of sediments or shellfish from one area to another (cysts are present in the gastrointestinal tract and in intervalvular liquid), as well as via ship ballast water (Garrett et al., 2014). Therefore, identification of the resistance forms and knowledge of their distribution area are important for preventing expansion and contamination. Similarly, determination of the key factors for growth and toxin production by $V$. rugosum is essential for better understanding the risk associated with this new species.

Temperature is the most important factor for the growth of $V$. rugosum. The data suggest that $V$. rugosum is a thermophilic species, consistent with its development in the Ingril lagoon from June to September and the highest concentrations of PnTX G found in mussels during this period (Abadie et al., 2016).

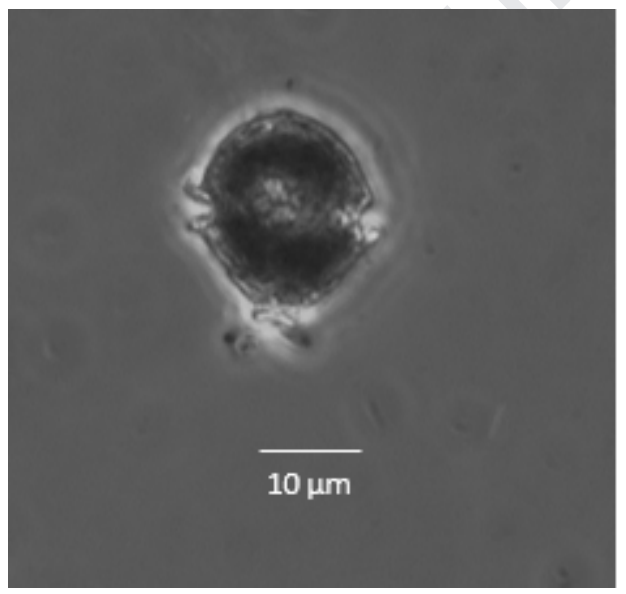

Figure 2: Micrograph of a cell of Vulcanodinium rugosum

\section{Hazard characterisation}

\subsection{Acute in vivo toxicity with purified PnTXs}


In vivo acute toxicity studies with purified toxins were reviewed using an analysis grid and assessed for quality using ToxRTool (Toxicological data Reliability assessment Tool, https://eurlecvam.jrc.ec.europa.eu/about-ecvam/archivepublications/toxrtool), a tool that ranks the studies according to the Klimisch rating (Klimish et al., 1997).

Data on the acute toxicity of purified PnTXs are very limited. Indeed, the available studies were carried out in only one species (mice), one sex (females, which are considered to be more sensitive than males by OECD guidelines) and with very few animals tested per dose (1 to 8 mice, when the number is specified). The results are presented in table 1.

Orally, only three studies are available and focused on PnTX E, F, G and H (Munday et al., 2012; Selwood et al., 2014; ANSES-University of Trieste-CNRS report, 2014 also published in Sosa et al., 2020). We did not find any information on the toxicity by the oral route for PtTXs (metabolites of certain PnTXs) and portimine (a toxin also produced by $V$. rugosum). Regarding the intraperitoneal (IP) route, four studies have been published on PnTX E, F, G and H and portimine (Munday et al., 2012; Selwood et al., 2010, 2013, 2014). We identified additional unpublished information regarding PnTX A (personal communication from J. Molgó), but did not find any robust information regarding PtTXs. Despite the limited number of studies for each PnTX and the low number of mice tested per dose, a consistent set of information enables outlining the main characteristics of the acute toxicity of this toxin group. Firstly, the toxicity of the PnTXs is rapid, with symptoms appearing within minutes of administration (whether oral or IP). This fact was already known, since PnTXs (like other cyclic imines) belong to the fast-acting toxins group (Efsa, 2010a). The second point relies on neurotoxic symptoms, quickly leading to the mouse's death by respiratory arrest. Clinical signs of toxicity, regardless of the route of administration and the PnTX analogue, include decreased mobility (sometimes preceded by an initial phase of hyperactivity immediately following administration), paralysis of the hind legs and breathing difficulties (Munday et al., 2012), with tremors and jumps also being reported (ANSESUniversity of Trieste-CNRS Report, 2014; Sosa et al., 2020). In the study by Munday et al. (2012), the authors reported that at sublethal doses (without specifying which ones), some mice recovered completely after exhibiting symptoms. LD50 values vary according to the PnTX analogue and route of administration (Table 1). Orally, LD50 values range from 25 to $2,800 \mu \mathrm{g} / \mathrm{kg}$ bw (for PnTX F and PnTX E respectively). The analogues tested can be ranked as follows in decreasing order of toxicity: PnTX F > PnTX G PnTX H >> PnTX E. By 
IP route, LD50 range from 13 to $115 \mu \mathrm{g} / \mathrm{kg}$ bw (for PnTX F and PnTX A respectively) and the analogues can be ranked as follows: PnTX F > PnTX G > PnTX E > PnTX H > PnTX A.

LD99 values for some PnTXs and PtTXs have been reported in the literature, but these data were considered not sufficiently reliable due to a lack of information on the protocol used (Uemura et al., 1995; Chou et al., 1996; McCauley et al., 1998; Takada et al., 2001).

Portimine has lower acute IP toxicity than that of PnTXs, with an estimated LD50 of 1,570 $\mu \mathrm{g} / \mathrm{kg} \mathrm{bw}$.

No effect was observed at 500 and $700 \mu \mathrm{g} / \mathrm{kg}$ bw (Selwood et al., 2013). The authors indicated that the signs of toxicity prior to death in mice appeared less rapidly after IP administration compared to PnTXs (without however mentioning which signs of toxicity were observed). Toxicity of portimine by oral administration is unknown.

Table 1: Acute in vivo toxicity in mice of PnTXs and portimine

\begin{tabular}{|c|c|c|c|c|c|}
\hline $\begin{array}{l}\text { Toxin } \\
\text { (purity) }\end{array}$ & $\begin{array}{l}\text { Route of } \\
\text { administration and } \\
\text { number of mice }\end{array}$ & $\begin{array}{l}\text { LD50 } \\
(\mu \mathrm{g} / \mathrm{kg} \mathrm{bw})\end{array}$ & $\begin{array}{l}\text { MTD } \\
(\mu \mathrm{g} / \mathrm{kg} \\
\mathrm{bw})\end{array}$ & References & Study quality \\
\hline PnTX E* & $\begin{array}{l}\text { Gavage } \\
\text { Number of mice not } \\
\text { specified (OECD GL } \\
425 \text { ) } \\
\text { Fed (non-fasted) mice }\end{array}$ & $\begin{array}{l}2800 \\
\text { Cl95: } 2380-3000\end{array}$ & 600 & $\begin{array}{l}\text { Munday et } \\
\text { al., } 2012\end{array}$ & $\begin{array}{l}\text { ToxRTool: } 13 \\
\text { Klimisch: } 2\end{array}$ \\
\hline $\begin{array}{l}\text { PnTX F* } \\
\text { PnTX F }\end{array}$ & $\begin{array}{l}\text { Gavage } \\
\text { Number of mice not } \\
\text { specified (OECD GL } \\
\text { 425) } \\
\text { Fed (non-fasted) mice } \\
\text { 16h fasted mice }\end{array}$ & $\begin{array}{l}25 \\
\text { C195: 19.1-35.1 } \\
\text { 29.9 } \\
\text { C195: 25-32 }\end{array}$ & $\begin{array}{l}9.9 \\
\\
\text { Not } \\
\text { determined }\end{array}$ & $\begin{array}{l}\text { Munday et } \\
\text { al., } 2012\end{array}$ & $\begin{array}{l}\text { ToxRTool: } 13 \\
\text { Klimisch: } 2\end{array}$ \\
\hline PnTX F* & $\begin{array}{l}\text { In cream cheese } \\
\text { Number of animals not } \\
\text { specified (OECD GL } \\
425 \text { ) } \\
\text { Fed (non-fasted) mice } \\
\text { In peanut butter } \\
\text { Number of mice not } \\
\text { specified (OECD GL } \\
425 \text { ) } \\
\text { Fed (non-fasted) mice } \\
\text { In dry mouse food } \\
\text { Number of mice not }\end{array}$ & $\begin{array}{l}50 \\
\text { Cl95: 39.4-62.8 } \\
50 \\
\text { Cl95: 37.9-71.5 } \\
50 \\
\text { Cl95: 37.9-71.5 }\end{array}$ & $\begin{array}{l}\text { Not } \\
\text { determined }\end{array}$ & $\begin{array}{l}\text { Munday et } \\
\text { al., } 2012\end{array}$ & $\begin{array}{l}\text { ToxRTool: } 13 \\
\text { Klimisch: } 2\end{array}$ \\
\hline
\end{tabular}




\begin{tabular}{|c|c|c|c|c|c|}
\hline $\begin{array}{l}\text { Toxin } \\
\text { (purity) }\end{array}$ & $\begin{array}{l}\text { Route of } \\
\text { administration and } \\
\text { number of mice }\end{array}$ & $\begin{array}{l}\text { LD50 } \\
(\mu \mathrm{g} / \mathrm{kg} \mathrm{bw})\end{array}$ & $\begin{array}{l}\text { MTD } \\
(\mu \mathrm{g} / \mathrm{kg} \\
\mathrm{bw})\end{array}$ & References & Study quality \\
\hline & $\begin{array}{l}\text { specified (OECD GL } \\
425 \text { ) } \\
\text { 16h fasted mice } \\
\text { In cream cheese, } 16 \mathrm{~h} \\
\text { fasted mice } \\
\text { In peanut butter, 16h } \\
\text { fasted mice }\end{array}$ & $\begin{array}{l}77 \\
\text { Cl95: not } \\
\text { calculated } \\
50 \\
\text { Cl95: } 39.4-62.8\end{array}$ & $\begin{array}{l}\text { Not } \\
\text { determined } \\
\text { Not } \\
\text { determined }\end{array}$ & & \\
\hline $\operatorname{PnTX} G^{*}$ & $\begin{array}{l}\text { Gavage } \\
\text { Number of mice not } \\
\text { specified (OECD GL } \\
425 \text { ) } \\
\text { Fed (non-fasted) mice }\end{array}$ & $\begin{array}{l}150 \\
\text { Cl95: 105-100 }\end{array}$ & 75 & $\begin{array}{l}\text { Munday et } \\
\text { al., } 2012\end{array}$ & $\begin{array}{l}\text { ToxRTool: } 13 \\
\text { Klimisch: } 2\end{array}$ \\
\hline $\begin{array}{l}\text { PnTX G } \\
\text { (declared } \\
\text { purity 100\%) }\end{array}$ & $\begin{array}{l}\text { Gavage } \\
\text { Groups of } 3 \text { to } 8 \text { mice }(8 \\
\text { for the control group; } 3 \\
\text { for the doses } 8,20,50, \\
120 \mu \mathrm{g} / \mathrm{kg} \mathrm{bw} ; 5 \text { for the } \\
\text { doses } 220,300,370, \\
400 \mu \mathrm{g} / \mathrm{kg} \mathrm{bw}) \\
\text { Mice fasted for } 3 \text { hours } \\
\text { before administration }\end{array}$ & $\begin{array}{l}208 \\
\text { Cl95: 155-281 }\end{array}$ & 120 & $\begin{array}{l}\text { ANSES- } \\
\text { University of } \\
\text { Trieste-CNRS } \\
\text { report, 2014; } \\
\text { Sosa et al., } \\
2020\end{array}$ & $\begin{array}{l}\text { ToxRTool: } 17 \\
\text { Klimisch: } 2\end{array}$ \\
\hline PnTX G* & $\begin{array}{l}\text { In cream cheese } \\
\text { Number of mice not } \\
\text { specified (OECD GL } \\
425 \text { ) } \\
\text { Fed (non-fasted) mice }\end{array}$ & $\begin{array}{l}400 \\
\text { CI95: } 380-470\end{array}$ & 153 & $\begin{array}{l}\text { Munday et } \\
\text { al., } 2012\end{array}$ & $\begin{array}{l}\text { ToxRTool: } 13 \\
\text { Klimisch: } 2\end{array}$ \\
\hline $\mathrm{PnTX} \mathrm{H}^{*}$ & $\begin{array}{l}\text { Gavage } \\
\text { Number of animals not } \\
\text { specified } \\
\text { Fasting not specified }\end{array}$ & $\begin{array}{l}163 \\
\text { Cl95: 139-175 }\end{array}$ & & $\begin{array}{l}\text { Selwood et } \\
\text { al., } 2014\end{array}$ & $\begin{array}{l}\text { ToxRTool: } 4 \\
\text { This low score is } \\
\text { due to the fact that } \\
\text { a lot of details are } \\
\text { missing in the } \\
\text { article, but this } \\
\text { team has already } \\
\text { described the } \\
\text { protocol for other } \\
\text { PnTXs }\end{array}$ \\
\hline
\end{tabular}

* Purity verified by NMR according to the authors but percentage not mentioned in the publication C195: 95\% confidence interval

MTD (Maximum Tolerated Dose): dose at which no mortality or clinical signs are observed

\begin{tabular}{|l|l|l|l|l|l|}
\hline $\begin{array}{l}\text { Toxin } \\
\text { (purity) }\end{array}$ & $\begin{array}{l}\text { Route of } \\
\text { administration and } \\
\text { number of mice }\end{array}$ & $\begin{array}{l}\text { LD50 } \\
(\mu \mathbf{g} / \mathbf{k g ~ b w})\end{array}$ & $\begin{array}{l}\text { MTD } \\
(\mu \mathbf{g} / \mathbf{k g} \\
\mathbf{b w})\end{array}$ & References & $\begin{array}{l}\text { Study } \\
\text { quality }\end{array}$ \\
\hline $\begin{array}{l}\text { Synthetic } \\
\text { PnTX A } \\
\text { (purity }>97 \%)\end{array}$ & $\begin{array}{l}\mathrm{IP} \\
\mathrm{n}=18 \text { mice, 9 doses } \\
\text { tested (1 to 3 } \\
\text { mice/dose) }\end{array}$ & 114.8 & & $\begin{array}{l}\text { J. Molgó } \\
\text { (personal } \\
\text { communication) }\end{array}$ & ToxRTool: 16 \\
\hline
\end{tabular}




\begin{tabular}{|c|c|c|c|c|c|}
\hline $\begin{array}{l}\text { Toxin } \\
\text { (purity) }\end{array}$ & $\begin{array}{l}\text { Route of } \\
\text { administration and } \\
\text { number of mice }\end{array}$ & $\begin{array}{l}\text { LD50 } \\
(\mu \mathrm{g} / \mathrm{kg} \mathrm{bw})\end{array}$ & $\begin{array}{l}\text { MTD } \\
(\mu \mathrm{g} / \mathrm{kg} \\
\mathrm{bw})\end{array}$ & References & $\begin{array}{l}\text { Study } \\
\text { quality }\end{array}$ \\
\hline & Fed (non-fasted) mice & & & & \\
\hline \multirow[t]{2}{*}{ PnTX E* } & $\begin{array}{l}\text { IP } \\
\text { Number of animals not } \\
\text { specified (OECD GL } \\
425)\end{array}$ & $\begin{array}{l}57 \text { (fed) } \\
\text { Cl95: } 39.7-75.3 \\
48 \text { (16h fasted) } \\
\text { Cl95: } 33.5-63.5\end{array}$ & $\begin{array}{l}22 \\
\text { Not } \\
\text { determined }\end{array}$ & $\begin{array}{l}\text { Munday et al., } \\
2012\end{array}$ & ToxRTool: 13 \\
\hline & $\begin{array}{l}\text { IP (OECD GL 425) } \\
\mathrm{n}=2 \text { at } 36 \mu \mathrm{g} / \mathrm{kg}, \\
\mathrm{n}=3 \text { at } 45 \mu \mathrm{g} / \mathrm{kg}, \\
\mathrm{n}=1 \text { at } 54 \mu \mathrm{g} / \mathrm{kg}, \\
\mathrm{n}=1 \text { at } 60 \mu \mathrm{g} / \mathrm{kg} .\end{array}$ & $\begin{array}{l}45 \text { (fed) } \\
\text { Cl95: 32-58 }\end{array}$ & & $\begin{array}{l}\text { Selwood et al., } \\
2010\end{array}$ & ToxRTool: 15 \\
\hline \multirow[t]{2}{*}{$\operatorname{PnTX} F^{*}$} & $\begin{array}{l}\text { IP } \\
\text { Number of animals not } \\
\text { specified (OECD GL } \\
425)\end{array}$ & $\begin{array}{l}12.7 \text { (fed) } \\
\text { Cl95: } 9.5-14.6 \\
14.9 \text { (16h fasted) } \\
\text { Cl95: 12.6-15.8 }\end{array}$ & $\begin{array}{l}3.2 \\
\text { Not } \\
\text { determined }\end{array}$ & $\begin{array}{l}\text { Munday et al., } \\
2012\end{array}$ & ToxRTool: 13 \\
\hline & $\begin{array}{l}\text { IP (OECD GL 425) } \\
\mathrm{n}=1 \text { at } 10.1 \mu \mathrm{g} / \mathrm{kg} \\
\mathrm{n}=1 \text { at } 12.7 \mu \mathrm{g} / \mathrm{kg} \\
\mathrm{n}=3 \text { at } 16.0 \mu \mathrm{g} / \mathrm{kg} \\
\mathrm{n}=2 \text { at } 20.1 \mu \mathrm{g} / \mathrm{kg}\end{array}$ & $\begin{array}{l}16 \text { (fed) } \\
\text { Cl95: 12-23 }\end{array}$ & & $\begin{array}{l}\text { Selwood et al., } \\
2010\end{array}$ & ToxRTool: 15 \\
\hline $\operatorname{PnTX} \mathrm{G}^{*}$ & $\begin{array}{l}\text { IP } \\
\text { Number of animals not } \\
\text { specified (OECD GL } \\
\text { 425) }\end{array}$ & $\begin{array}{l}48 \text { (fed) } \\
\text { Cl95: } 36.3-68.1 \\
42.7 \text { (16h fasted) } \\
\text { Cl95: } 40-50\end{array}$ & $\begin{array}{l}18.8 \\
\text { Not } \\
\text { determined }\end{array}$ & $\begin{array}{l}\text { Munday et al., } \\
2012\end{array}$ & ToxRTool: 13 \\
\hline PnTX G* & $\begin{array}{l}\text { IP (OECD GL 425) } \\
\mathrm{n}=2 \text { at } 40 \mu \mathrm{g} / \mathrm{kg} \text {, } \\
\mathrm{n}=3 \text { at } 50 \mu \mathrm{g} / \mathrm{kg} \text {, } \\
\mathrm{n}=1 \text { at } 60 \mu \mathrm{g} / \mathrm{kg} .\end{array}$ & $\begin{array}{l}50 \text { (fed) } \\
\text { Cl95: 35-66 }\end{array}$ & & $\begin{array}{l}\text { Selwood et al., } \\
2010\end{array}$ & ToxRTool: 15 \\
\hline $\begin{array}{l}\text { Synthetic } \\
\text { PnTX G } \\
\text { (purity > 97\%) }\end{array}$ & $\begin{array}{l}\text { IP } \\
\text { Number of animals not } \\
\text { specified }\end{array}$ & 65.8 & & $\begin{array}{l}\text { J. Molgó } \\
\text { (personal } \\
\text { communication) }\end{array}$ & ToxRTool: 16 \\
\hline $\mathrm{PnTX} \mathrm{H}^{*}$ & $\begin{array}{l}\text { IP } \\
\text { Number of animals not } \\
\text { specified } \\
\text { Fasting not specified }\end{array}$ & $\begin{array}{l}67 \\
\text { Cl95: 63-79 }\end{array}$ & & $\begin{array}{l}\text { Selwood et al., } \\
2014\end{array}$ & $\begin{array}{l}\text { ToxRTool: } 4 \\
\text { This low score is } \\
\text { due to the fact } \\
\text { that a lot of } \\
\text { details are } \\
\text { missing in the } \\
\text { article, but this } \\
\text { team has already } \\
\text { described the } \\
\text { protocol for other } \\
\text { PnTXs }\end{array}$ \\
\hline Portimine ${ }^{*}$ & $\begin{array}{l}\text { IP } \\
\text { Number of animals not }\end{array}$ & $\begin{array}{l}1570 \\
\text { Cl95: 1269-3080 }\end{array}$ & $\begin{array}{l}\text { No effect at } \\
500 \text { and } \\
700\end{array}$ & $\begin{array}{l}\text { Selwood et al., } \\
2013\end{array}$ & $\begin{array}{l}\text { ToxRTool: } 4 \\
\text { This low score is } \\
\text { due to the fact }\end{array}$ \\
\hline
\end{tabular}




\begin{tabular}{|l|l|l|l|l|l|}
\hline $\begin{array}{l}\text { Toxin } \\
\text { (purity) }\end{array}$ & $\begin{array}{l}\text { Route of } \\
\text { administration and } \\
\text { number of mice }\end{array}$ & $\begin{array}{l}\text { LD50 } \\
(\mu \mathrm{g} / \mathbf{k g ~ b w})\end{array}$ & $\begin{array}{l}\text { MTD } \\
(\mu \mathbf{g} / \mathbf{k g} \\
\mathbf{b w})\end{array}$ & References & $\begin{array}{l}\text { Study } \\
\text { quality }\end{array}$ \\
\hline & $\begin{array}{l}\text { specified } \\
\text { Fasting not specified }\end{array}$ & & & & $\begin{array}{l}\text { that a lot of } \\
\text { details are } \\
\text { missing in the } \\
\text { article, but this } \\
\text { team has already } \\
\text { described the } \\
\text { protocol for other } \\
\text { PnTXs }\end{array}$ \\
\hline
\end{tabular}

* Purity verified by NMR according to the authors but percentage not mentioned in the publication Cl95: 95\% confidence interval

MTD (Maximum Tolerated Dose): dose at which no mortality or clinical signs are observed

\subsection{Subchronic and chronic toxicity}

No repeated dose toxicity studies were identified in the literature.

\subsection{Mode of action and extrapolation to humans}

We reviewed the data available on the mode of action of PnTXs (Delcourt et al., 2019). PnTXs are high-affinity competitive antagonists of nicotinic acetylcholine receptors (nAChRs) (Araoz et al., 2011; Hellyer et al., 2015). Their lethal effects in mice studies are consistent with the inhibition of muscle nAChRs, inducing respiratory distress and paralysis (Delcourt et al., 2019). PnTX E, F, G and A block nerve stimulation-induced skeletal muscle contraction, but do not alter muscle contraction caused by direct stimulation of isolated adult rodent muscles (Hellyer et al., 2013; Benoit et al., 2019).

The clinical effects observed in humans after exposure to compounds (drugs, natural toxins) whose pharmacology is comparable to that of PnTXs have been described (Delcourt et al., 2019). Possible symptoms in humans due to PnTXs could include muscle weakness (myasthenic-like syndrome), dyspnea, anticholinergic syndrome, dysautonomia, pyramidal syndrome, and seizures.

\subsection{Development of a health value}

The methodology set in ANSES's guide for the development of toxicological reference values (2017) was followed.

\subsubsection{Choice of the key study}


Two acute oral toxicity studies in mice with purified PnTX G were identified (Munday et al., 2012; ANSES-University of Trieste-CNRS report, 2014 also published in Sosa et al., 2020). The key study selected was the one carried out by the Department of Life Sciences at the University of Trieste with funding from the DGAL and DGS (ANSES-University of Trieste-CNRS report, 2014; Sosa et al., 2020), which obtained the highest score (17 out of 21 with ToxRTool, corresponding to a Klimisch score of 2 reliable with restriction).

In this study, groups of three to five 4 weeks-old female SD-1 mice received a single administration of purified PnTX G by gavage at a dose of $8,20,50,120,220,300,370$ or $450 \mu \mathrm{g} / \mathrm{kg}$ bw. A control group of eight mice was included. Mice were fasted for 3 hours before gavage; food was given back again ad libitum 2 hours after administration during the 24-hour observation period. Lethality, clinical signs of toxicity, histological analysis of several organs and blood biochemistry were recorded.

The results regarding lethality and the observed symptoms are shown in Table 2. Administration of PnTX G resulted in mouse lethality from $220 \mu \mathrm{g}$ PnTX G/kg bw (3/5 mice, in $22 \mathrm{~min})$. No lethality was observed at the doses of $8,20,50$ and $120 \mu \mathrm{g} / \mathrm{kg}$ bw. All mice (5/5) died at the dose of $370 \mu \mathrm{g} / \mathrm{kg}$ bw (survival time between 13 and $18 \mathrm{~min}$ ). The LD50 for PnTX G was calculated at $208 \mu \mathrm{g} / \mathrm{kg}$ bw (95\% confidence interval $=155-281 \mu \mathrm{g} / \mathrm{kg} \mathrm{bw})$.

Before death, the main symptoms were neurotoxic, i.e. prostration, tremors, jumps, abdominal breathing, hypothermia, hind leg paralysis and cyanosis. No macroscopic organ changes were observed during necropsy of the mice treated with PnTX G. Histological analysis of major organs and tissues revealed only minor changes in the small intestine of mice given PnTX G at doses equal to or greater than $300 \mu \mathrm{g} / \mathrm{kg}$ bw (moderate mucosal degeneration, villous atrophy). No differences in biochemical blood parameters were found between treated and control mice (Sosa et al., 2020).

Table 2: Lethality and clinical signs of toxicity in mice after single administration by gavage of purified PnTX G (ANSES-University of Trieste-CNRS Report, 2014; Sosa et al., 2020)

\begin{tabular}{|l|l|l|l|}
\hline $\begin{array}{l}\text { Purified PnTX G } \\
\text { dose }\end{array}$ & Lethality & $\begin{array}{l}\text { Survival time } \\
\text { (h:min) }\end{array}$ & Clinical signs of toxicity \\
\hline Control & $0 / 8$ & - & - \\
\hline $8 \mu \mathrm{g} / \mathrm{kg} \mathrm{bw}$ & $0 / 3$ & - & - \\
\hline $20 \mu \mathrm{g} / \mathrm{kg} \mathrm{bw}$ & $0 / 3$ & - & - \\
\hline $50 \mu \mathrm{g} / \mathrm{kg} \mathrm{bw}$ & $0 / 3$ & - & - \\
\hline $120 \mu \mathrm{g} / \mathrm{kg} \mathrm{bw}$ & $0 / 3$ & - & - \\
\hline $220 \mu \mathrm{g} / \mathrm{kg}$ bw & $3 / 5$ & $00: 20 ; 00: 22 ; 00: 22$ & prostration, tremors, jumps, abdominal \\
\hline
\end{tabular}


Journal Pre-proof

\begin{tabular}{|l|l|l|l|}
\hline & & & $\begin{array}{l}\text { breathing, hypothermia, hind leg paralysis, } \\
\text { cyanosis }\end{array}$ \\
\hline $300 \mu \mathrm{g} / \mathrm{kg}$ bw & $4 / 5$ & $\begin{array}{l}00: 12 ; 00: 13 ; 00: 17 ; \\
00: 23\end{array}$ & $\begin{array}{l}\text { prostration, tremors, jumps, abdominal } \\
\text { breathing, hypothermia, hind leg paralysis, } \\
\text { cyanosis }\end{array}$ \\
\hline $370 \mu \mathrm{g} / \mathrm{kg}$ bw & $5 / 5$ & $\begin{array}{l}00: 13 ; 00: 15 ; 00: 16 ; \\
00: 17 ; 00: 18\end{array}$ & $\begin{array}{l}\text { prostration, tremors, jumps, abdominal } \\
\text { breathing, hypothermia, hind leg paralysis, } \\
\text { cyanosis }\end{array}$ \\
\hline $450 \mu \mathrm{g} / \mathrm{kg}$ bw & $5 / 5$ & $\begin{array}{l}00: 12 ; 00: 12 ; 00: 15 ; \\
00: 16 ; 00: 29\end{array}$ & $\begin{array}{l}\text { prostration, tremors, jumps, abdominal } \\
\text { breathing, hypothermia, hind leg paralysis, } \\
\text { cyanosis }\end{array}$ \\
\hline
\end{tabular}

\subsubsection{Choice of the critical dose}

Based on the data from the key study, two approaches were explored:

- First approach: the $\mathbf{1 2 0} \mu \mathrm{g}$ PnTX G/kg bw dose was selected as the maximum tolerated dose (MTD), i.e. the dose at which no effect is observed in the studied parameters over a 24-hour period after treatment.

- Second approach: calculation of a benchmark dose ${ }^{1}$ from a response level of $10 \%$ mortality (PROAST Web software, RIVM, v. 65.2). The model that best fitted the experimental data according to the Akaike Information Criterion (AIC) was the probit model, for which the BMDL $95 \%$ was $69.1 \mu \mathrm{g}$ PnTX G/kg bw of mouse.

It is unusual to use data on mouse mortality from single oral administration to derive a health reference value. This is justified by the fact that the mouse mortality occurs rapidly and there is a very small difference between a dose with no signs of toxicity and a lethal dose.

A response level of $10 \%$ (for lethality) is considered high but was exceptionally selected in this expert appraisal because the results obtained with a response level of $1 \%$ were regarded as too uncertain due to the small number of mice tested in the study.

The results obtained in the other acute oral toxicity study of purified PnTX G with non-fasted mice (Munday et al., 2012) were consistent with those of the key study selected conducted by the Department of Life Sciences at the University of Trieste:

i. The LD50 was $150 \mu \mathrm{g}$ PnTX G/kg bw $(95 \% \mathrm{Cl}=105-199 \mu \mathrm{g} / \mathrm{kg} \mathrm{bw})$;

\footnotetext{
${ }^{1}$ The benchmark dose is a dose producing a measurable effect corresponding to a given response level compared to a control group. The lower limit of its $95 \%$ or $90 \%$ confidence interval (BMDL $95 \%$ or BMDL $90 \%$ ) is most often used. This approach is based on modelling of the experimental data taking into account the entire doseresponse curve (ANSES 2017a).
} 
ii. The dose tested without lethality and with no apparent sign of neurotoxicity was $75 \mu \mathrm{g} P$ TX G/kg bw.

\subsubsection{Choice of uncertainty factors}

257

258

259

260

261

262

263

264

265

266

267

268

269

270

\section{1}

272

273

274

275

276

277

Uncertainty factors were identified for both approaches explored when establishing the critical dose:

- First approach: the dose of $120 \mu \mathrm{g} P \mathrm{PTX} \mathrm{G} / \mathrm{kg}$ bw was selected as the maximum tolerated dose (MTD). The associated overall uncertainty factor was 900 :

○ inter-species uncertainty factor: $U_{\mathrm{A}}=10$

$\circ$ inter-individual uncertainty factor: $\mathrm{UF}_{\mathrm{H}}=10$

o other factors: $U F_{D}=3$ (insufficient data) and 3 (to take into account the severity and pattern of the dose-response curve)

- Second approach: the BMDL of $69.1 \mu \mathrm{g}$ PnTX G/kg bw was chosen as the point of departure. The associated overall uncertainty factor was 525 :

o allometric adjustment factor: 7 for the mouse

$\circ \mathrm{UF}_{\mathrm{A}}=2.5$ for the toxicodynamic component

$\circ \mathrm{UF}_{\mathrm{H}}=10$

- $\mathrm{UF}_{\mathrm{D}}=3$ (insufficient data).

\subsubsection{Proposed health-based guidance value}

Due to insufficient data for the hazard characterisation of PnTX G, the guidance value derived is considered as a provisional acute benchmark value.

The provisional acute benchmark value is $\mathbf{0 . 1 3} \boldsymbol{\mu g} \mathbf{P n T X} \mathbf{G} / \mathbf{k g} \mathbf{b w}$, (Table 3) regardless of the approach used $^{2}$ (MTD or BMDL).

Table 3: Table summarising development of the provisional acute benchmark value for PnTX G

\begin{tabular}{|l|l|l|l|l|}
\hline $\begin{array}{l}\text { Critical effect } \\
\text { Key study }\end{array}$ & $\begin{array}{l}\text { Critical dose } \\
\text { for the mouse }\end{array}$ & UF & $\begin{array}{l}\text { Provisional acute } \\
\text { benchmark value } \\
\text { for humans }\end{array}$ & $\begin{array}{l}\text { Confidence } \\
\text { level }\end{array}$ \\
\hline
\end{tabular}

\footnotetext{
2 MTD approach: $(120 \mu \mathrm{g}$ PnTX G/kg bw) / $(10 \times 10 \times 3 \times 3)=120 / 900=0.1333 \mu \mathrm{g}$ PnTX G/kg bw
} BMDL approach: $69.1 \mu \mathrm{g}$ PnTX G/kg bw $) /(7 \times 2.5 \times 10 \times 3)=69.1 / 525=0.1316 \mu \mathrm{g}$ PnTX G/kg bw 


\section{Journal Pre-proof}

\begin{tabular}{|c|c|c|c|c|c|}
\hline $\begin{array}{l}\text { First } \\
\text { approach }\end{array}$ & $\begin{array}{l}\text { Critical effect: } \\
\text { absence of } \\
\text { mortality and } \\
\text { symptoms in mice } \\
24 \text { hours after a } \\
\text { single oral } \\
\text { administration by } \\
\text { gavage of purified } \\
\text { PnTX G } \\
\text { Kev studv. }\end{array}$ & $\begin{array}{l}\text { Maximum } \\
\text { tolerated dose } \\
\text { of } 120 \mu \mathrm{g} \mathrm{PnTX} \\
\mathrm{G} / \mathrm{kg} \mathrm{bw}\end{array}$ & $\begin{array}{l}\text { Total factor: } 900 \\
\mathrm{UF}_{\mathrm{A}}=10 \\
\mathrm{UF}_{\mathrm{H}}=10 \\
\mathrm{UF}_{\mathrm{D}}=9 \text { ( } 3 \text { for } \\
\text { insufficient data } \\
\text { and } 3 \text { for the } \\
\text { severity and } \\
\text { pattern of the } \\
\text { dose-response } \\
\text { curve). }\end{array}$ & $\begin{array}{l}0.13 \mu \mathrm{g} \text { PnTX G/kg } \\
\text { bw }\end{array}$ & Moderate \\
\hline $\begin{array}{l}\text { Second } \\
\text { approach }\end{array}$ & $\begin{array}{l}\text { ANSES-University } \\
\text { of Trieste-CNRS } \\
\text { report, 2014; Sosa } \\
\text { et al., 2020 }\end{array}$ & $\begin{array}{l}\text { BMDL of } 69.1 \\
\mu \mathrm{g} \text { PnTX G/kg } \\
\text { bw }\end{array}$ & $\begin{array}{l}\text { Total factor: } 525 \\
\text { Allometric } \\
\text { adjustment: } 7 \text { for } \\
\text { the mouse } \\
U_{A}=2.5 \\
U_{A}=10 \\
U_{D}=3 \text { for } \\
\text { insufficient data }\end{array}$ & $\begin{array}{l}0.13 \mu \mathrm{g} P n T X \text { G } / \mathrm{kg} \\
\text { bw }\end{array}$ & Moderate \\
\hline
\end{tabular}

\subsubsection{Proposed maximum tolerable concentration of PnTX G in shellfish}

Based on the provisional acute benchmark value of $0.13 \mu \mathrm{g}$ PnTX G/kg bw, a default serving size of $400 \mathrm{~g}$ of shellfish (EFSA 2010b) and a default body weight of $70 \mathrm{~kg}$, the concentration not to be exceeded in shellfish would be $23 \mu \mathrm{g}$ PnTX G/kg of total meat.

\subsubsection{Confidence level}

An overall confidence level moderate was assigned to the provisional acute benchmark value based on the following criteria:

The literature review revealed that there were few data on the acute oral toxicity of purified PnTXs and none on repeated administration. In fact, only two acute oral toxicity studies conducted on a single species (mice) and sex (females, which are considered to be more sensitive than males) have been published. The lack of data in another rodent species (rats) and of knowledge on the toxicokinetics and toxicodynamics of PnTXs is underlined. 
The key study is an acute toxicity study with a single oral administration. Its objective was to study mouse mortality and define a median lethal dose (LD50). Signs of neurological toxicity were also observed and are consistent with the known mode of action of PnTXs.

We stress that it is unusual to use data on mouse mortality from single oral administration to derive a health reference value. This is justified by the fact that the mouse mortality occurs rapidly and there is a very small difference between a dose with no signs of toxicity and a lethal dose.

- Level of confidence in the choice of the key study: Moderate/High

The key study was analysed using ToxRTool and obtained a total score of 17 (out of 21), corresponding to a score of 2 using the Klimisch method (reliable study with restriction).

- Level of confidence in the choice of the critical dose: High

Two approaches were explored for selecting the critical dose from the key study data. The first approach retained a maximum tolerated dose (MTD), at which there is no mortality or signs of toxicity in mice during the 24-hour observation period (which is considered sufficient because PnTXs are fastacting toxins, with neurotoxic signs in mice occurring within 30 minutes of administration). The second approach modelled the dose-response relationship (lethality) to calculate a BMDL.

This overall confidence level may be reassessed when new acute oral toxicity data become available for PnTX G or other toxins produced by V. rugosum.

\section{Occurrence of PnTXs in shellfish}

\subsection{Ingril lagoon}

As soon as PnTX G was identified in France (2011), a retrospective analysis of the samples from 2009 to 2012 was conducted by Ifremer, which revealed the kinetics of shellfish contamination as a function of time. The maximum annual concentrations were $261,1244,568$ and $652 \mu \mathrm{g} / \mathrm{kg}$ of total mussel meat for 2009, 2010, 2011 and 2012 respectively (Table 4). Concentrations in mussels were higher than those observed in clams, when shellfish were sampled simultaneously (Table 5).

To track this phenomenon and maintain monitoring for PnTXs, sampling of Ingril mussels was carried out monthly between 2013 and 2017 by Ifremer. The results show that PnTX G peaks were observed 
between June and September, but the maximum values varied according to the year (887 in 2013, 918 in 2014, 1143 in 2015, 600 in 2016 and 640 in 2017, expressed in $\mu \mathrm{g} / \mathrm{kg}$ of total meat).

Table 4: Data on concentrations of PnTX G in mussels from Ingril lagoon from 2010 to 2017

$(\mu \mathrm{g} / \mathrm{kg}$ total meat)

\begin{tabular}{|l|l|l|l|l|l|l|l|l|}
\hline Year & $\mathbf{2 0 1 0}$ & $\mathbf{2 0 1 1}$ & $\mathbf{2 0 1 2}$ & $\mathbf{2 0 1 3}$ & $\mathbf{2 0 1 4}$ & $\mathbf{2 0 1 5}$ & $\mathbf{2 0 1 6}$ & $\mathbf{2 0 1 7}$ \\
\hline Number of samples & 30 & 32 & 24 & 12 & 27 & 2 & 13 & 10 \\
\hline Min & 45.4 & 36.6 & 11.0 & 49.5 & 22.6 & 572 & 44.0 & 52.9 \\
\hline Max & 1244 & 568 & 652 & 887 & 918 & 1143 & 600 & 640 \\
\hline Mean & 223 & 227 & 209 & 293 & 247 & 858 & 278 & 294 \\
\hline
\end{tabular}

Table 5: Data on concentrations of PnTX G in mussels and clams from Ingril lagoon from 2010 to $2012(\mu \mathrm{g} / \mathrm{kg}$ total meat)

\begin{tabular}{|l|l|l|}
\hline & Mussels & Clams \\
\hline Number of samples & 86 & 20 \\
\hline Min & 11.0 & 13.6 \\
\hline Max & 1244 & 95.3 \\
\hline Mean & 217 & 28.1 \\
\hline
\end{tabular}

\subsection{Other Mediterranean lagoons}

In addition to the monitoring carried out in the Ingril lagoon, screening for PnTX G in wild mussel samples took place the same week in four other Mediterranean lagoons in 2013 (Table 6). Maximum levels of PnTX G increased in the following order: Parc Leucate $(11 \mu \mathrm{g} / \mathrm{kg}$ of total meat) $>$ Thau (15 $\mu \mathrm{g} / \mathrm{kg})>$ Le Prevost $(54 \mu \mathrm{g} / \mathrm{kg})>$ Vic $(89 \mu \mathrm{g} / \mathrm{kg})>$ Ingril $(887 \mu \mathrm{g} / \mathrm{kg})$.

Table 6: Data on concentrations of PnTX G in mussels from several Mediterranean lagoons in $2013(\mu \mathrm{g} / \mathrm{kg}$ total meat)

\begin{tabular}{|l|l|l|l|l|l|}
\hline & Parc Leucate & Thau & Le Prévost & Vic & Ingril \\
\hline Number of samples & 12 & 11 & 12 & 11 & 12 \\
\hline Min & 0.68 & 1.4 & 11.8 & 12.3 & 49.5 \\
\hline
\end{tabular}


Journal Pre-proof

\begin{tabular}{|l|l|l|l|l|l|}
\hline Max & 10.7 & 14.7 & 53.9 & 89.0 & 887 \\
\hline Mean & 3.4 & 10.0 & 26.2 & 48.4 & 293 \\
\hline
\end{tabular}

\subsection{Atlantic and Corsican coasts}

In France, the EMERGTOX scheme for monitoring the emergence of marine biotoxins in shellfish was set up by the DGAL to complement national surveillance schemes for regulated toxins (REPHYTOX, the DGAL's surveillance plan). Its purpose is to bring to light any possible hazard associated with the presence in shellfish of known regulated and unregulated lipophilic toxins, either identified in France or that could be introduced into France via ballast water or commercial trade between countries.

Since 2018, this scheme enables the targeted analysis by chemical methods of PnTXs in mussels and oysters from eleven areas located all along the French metropolitain coasts. During this first year of monitoring, three of these areas (Ingril, Le Scoré in Brittany and the Diana lagoon in Corsica) were affected by the presence of PnTXs, mainly PnTX G and to a lesser degree PnTX A (only in Ingril). Of the three affected areas, the Ingril lagoon remains the most heavily contaminated area (with concentrations detected every month, varying from 40 to $2614 \mu \mathrm{g}$ PnTX G/kg of digestive gland). The levels found at Le Scoré and Diana were low (maximum around $10 \mu \mathrm{g}$ PnTX G/kg of digestive gland). The concentrations of PnTX A detected at Ingril ranged from 6 to $32 \mu \mathrm{g} / \mathrm{kg}$ of digestive gland.

We believe it is important to point out that the presence of PnTXs in France is not limited to Mediterranean lagoons. Given that global warming is making ecophysiological conditions more favourable to the development of $V$. rugosum, vigilance should be maintained along the Atlantic coast, since the detection of PnTXs in mussels from Brittany points out the presence of the dinoflagellate producer also in these waters.

\subsection{Outside France}

The literature review concluded that very limited data on PnTX levels in shellfish from Northern and Southern Europe, Canada and New Zealand have been published. Among the eight studies reviewed (MacKenzie et al., 2011; Rundberget, et al., 2011; McCarron et al., 2012 ; McNabb et al., 2012; Garcia-Altares et al., 2014; Rambla Alegre et al., 2018; Lamas et al., 2019; Otero et al., 2019), the highest reported levels of PnTX G in mussels were $115 \mu \mathrm{g} / \mathrm{kg}$ in Norway (Rundberget et al., 2011), 83 $\mu \mathrm{g} / \mathrm{kg}$ in Canada (McCarron et al., 2012) and $59 \mu \mathrm{g} / \mathrm{kg}$ in Spain (Garcia-Altares et al., 2014). These 
and $1244 \mu \mathrm{g} / \mathrm{kg}$, depending on the year). It should be noted that the study by Rambla-Alegre et al. (2018) reported the persistence of PnTX G in samples of canned mussels (up to $12 \mu \mathrm{g} / \mathrm{kg}$ ).

Lastly, ANSES sent a questionnaire to the European Food Safety Authority (EFSA) network of focal points on 15 February 2018, to which 16 Member States replied. At the time of the request, none of the responding health agencies had conducted a health risk assessment for PnTXs. Some respondents provided contamination data in shellfish from their country. Most of the data were already published in a scientific journal and had been identified in our literature search. Some unpolished data were also provided but without information about the performance of the analytical method used. In conclusion, the concentrations of PnTX G measured in mussels from Ingril are the highest reported in the world to date.

\section{Dietary exposure}

\subsection{Food consumption data}

A consumption survey on seafood products in France (CONSOMER) was conducted in 2016-2017 as part of a research agreement between ANSES and CREDOC (2015-CRD-25). The aim of the survey was to assess seafood consumption by an adult population (over 18 years of age) living in coastal areas and with access to local sources of supply. The database includes answers from 2481 adults. Only data for the Mediterranean population were used in the present work, including 821 adults (Table 7).

Table 7: Consumption data of mussels and clams from CONSOMER survey (Mediterranean population only), daily portion size.

\begin{tabular}{|c|c|c|c|}
\cline { 2 - 4 } \multicolumn{1}{c|}{} & Number of consumers & Mean amount in g/day & P95 in g/day \\
\hline Mussels & 582 & 91.2 & 200 \\
\hline Clams & 140 & 19.8 & 40 \\
\hline
\end{tabular}

\subsection{Contamination data}

Data on concentrations of PnTX G in mussels and clams from several Mediterranean lagoons from 2010 to 2017 were provided to ANSES by Ifremer (Table 8). Three scenarios were selected, depending on the site where the shellfish were sampled: 
- "All lagoons" scenario: contamination data of all mussels on the one hand and all clams on the other (from all the lagoons studied);

- "Ingril" scenario: contamination data ONLY from the Ingril lagoon, for mussels on the one hand and clams on the other;

- "Except Ingril" scenario: contamination data from all lagoons (Vic, le Prévost, Parc Leucate and Thau) except "Ingril", for mussels only (no clams sampled in other lagoons).

Table 8: Concentrations of PnTX G in mussels and clams from several Mediterranean lagoons

\begin{tabular}{|l|l|l|l|}
\cline { 2 - 4 } \multicolumn{1}{c|}{} & \multirow{2}{*}{$\begin{array}{l}\text { Number of samples } \\
\text { of mussels }\end{array}$} & \multicolumn{3}{|l|}{ Concentration of PnTX G $(\boldsymbol{\mu g} / \mathbf{k g}$ total meat) } \\
\cline { 3 - 4 } \multicolumn{1}{c|}{} & & Mean & P95 \\
\hline All lagoons & 196 & 196 & 633 \\
\hline Ingril & 150 & 249 & 712 \\
\hline Except Ingril & 46 & 21.7 & 60.3 \\
\hline & \multirow{2}{*}{$\begin{array}{l}\text { Number of samples } \\
\text { of clams }\end{array}$} & Concentration of PnTX G $(\boldsymbol{\mu g} / \mathbf{k g}$ total meat) \\
\cline { 2 - 4 } & 20 & Mean & P95 \\
\hline All lagoons & 28.1 & 57 \\
\hline Ingril & 20 & 28.1 & 57 \\
\hline Except Ingril & 0 & No data & No data \\
\hline
\end{tabular}

${ }^{*}$ Number of samples of mussels in other lagoons than Ingril are described in Table 6.

\subsection{Method to calculate exposure}

411 From the individual consumption data and the contamination data, exposure was calculated according

to the following equation:

$$
E_{i}=\sum_{k=1}^{n} \frac{C_{i, k} \times L_{k}}{B W_{i}}
$$

413 where:

$414-E_{i}$ is the total daily exposure of individual i associated with the consumption of food $\mathrm{k}(\mu \mathrm{g} / \mathrm{kg}$ of body 415 weight/day);

$416-C_{i, k}$ is the consumption of food $\mathrm{k}$ by individual $\mathrm{i}(\mathrm{kg} / \mathrm{d})$ (serving size for acute exposure); 
- $L_{k}$ is the PnTX G contamination of food k ( $\mu \mathrm{g} / \mathrm{kg}$ of fresh weight) ( $95^{\text {th }}$ percentile for acute exposure);

- $\mathrm{BW}_{i}$ is the body weight of individual $\mathrm{i}(\mathrm{kg})$.

\section{Risk characterisation}

\subsection{Results}

A comparison of acute exposure estimates was made with the provisional acute benchmark value of $0.13 \mu \mathrm{g}$ PnTX G/kg of body weight. A percentage of the population exceeding this value was calculated, firstly in the total population and secondly for consumers of mussels and clams only (Table 9).

Table 9: Acute exposure associated with consumption of mussels and clams (CONSOMER,

\section{Mediterranean area) for adults (in $\mu \mathrm{g}$ PnTX G/kg bw)}

\begin{tabular}{|l|l|l|l|l|l|l|l|l|}
\hline & \multicolumn{3}{|l|}{$\begin{array}{l}\text { Total population } \\
\text { (Mediterranean area) }\end{array}$} & \multicolumn{2}{l|}{$\begin{array}{l}\text { Consumers only } \\
\text { (Mediterranean area) }\end{array}$} & \multicolumn{2}{l|}{$\begin{array}{l}\text { Provisional acute benchmark } \\
\text { value (PABV) exceeded }\end{array}$} \\
\hline & $\mathrm{n}$ & Ave_pop & P95_pop & n_cons & Ave_cons & P95_cons & $\%>$ PABV & $\%$ > PABV_cons \\
\hline All lagoons & 821 & 0.590 & 1.572 & 591 & 0.816 & 1.733 & 71 & 100 \\
\hline Ingril & 821 & 0.663 & 1.767 & 591 & 0.917 & 1.946 & 71 & 100 \\
\hline $\begin{array}{l}\text { Except Ingril } \\
\text { (mussels } \\
\text { only }\end{array}$ & 821 & 0.056 & 0.149 & 582 & 0.079 & 0.167 & 7.3 & 10.23 \\
\hline
\end{tabular}

$431 \mathrm{n}$ : number of adult individuals in the population monitored during the survey (this population includes consumers and non-consumers of mussels and clams from the first column) P95_pop: exposure to the $95^{\text {th }}$ percentile calculated in the population $(\mu \mathrm{g} / \mathrm{kg} \mathrm{bw} / \mathrm{d})$ bw

$440 \%>$ PABV_cons: percentage of consumer population only exceeding the provisional acute benchmark value of 
These results show that in the tested scenarios including the contamination data from the Ingril lagoon the provisional acute benchmark value would be exceeded in $71 \%$ of adults according to the consumption data from the CONSOMER study for the Mediterranean area (in the scenario including non-consumers of mussels and clams). If only individuals consuming mussels and clams are considered, this proportion increases to $100 \%$. In the tested scenario excluding the contamination data from the Ingril lagoon, the provisional acute benchmark value would be exceeded in $7 \%$ of the total Mediterranean population and in $10 \%$ of the population of consumers.

\subsection{Conclusion in terms of health concern}

Considering the percentage of the French population for which the provisional acute benchmark value would be exceeded in the "Except Ingril" scenario, there may be a health concern related to the consumption of shellfish contaminated with PnTXs from these Mediterranean lagoons. Estimates were not made for the other French sites where PnTXs were detected in mussels (Le Scoré, Diana) because the contamination was measured only in the digestive glands, and the distribution of PnTXs between the digestive gland and the total meat is not known.

\section{Recommendations for surveillance}

\subsection{Environmental surveillance}

Several studies on the ecology of the dinoflagellate $V$. rugosum have been carried out in vitro and in situ. However, its origin and the determinism of its blooms in natural environments remain to be elucidated. While the contamination of molluscs by PnTXs in some areas is undeniable, it remains difficult to establish the relationship with $V$. rugosum blooms as the observation of the pelagic phase in the water column is challenging. Official surveillance of shellfish production areas based on the identification and counting of toxic phytoplanktonic species in the water column is therefore ill-suited to this species.

Several monitoring options can be proposed:

1) Regarding dinoflagellate surveillance, monitoring of the benthic population of this organism in risk areas is recommended. It is essential to sample the macroalgae present in the area, in order to collect $V$. rugosum cells. The protocol set up for "Ostreopsis" monitoring and tested in the study by Abadie et al. (2018) shows that such methodology is adequate. 
2) Alongside the monitoring of $V$. rugosum, more systematic surveillance of the presence of PnTX A and G toxins in molluscs should be considered. The extraction protocol for PnTXs is identical to the one used for official monitoring of lipophilic toxins in the French shellfish production areas (REPHYTOX). Although an additional step for LC-MS/MS analysis is required, the cost remains moderate. A systematic screening for PnTXs in total meat could be added to the REPHYTOX analyses of lipophilic toxins, and not only on samples taken for the EMERGTOX scheme, that focuses only on the digestive gland.

Such proposal will enable estimating and monitoring the presence of PnTXs in bivalve molluscs in national production areas.

\subsection{Health monitoring, reporting and procedures}

To carry on with this issue, ANSES is working on raising awareness among health professionals of the potential neurological symptoms that could be associated with PnTXs poisoning in humans (Delcourt at al., 2019). An epidemiological study is currently underway with the objective to identify potential human cases related to shellfish consumption and PnTX exposure in France.

\section{Conclusion}

This work points out that, in case of high consumption and/or high contamination, the provisional acute benchmark value for PnTX G could be exceeded, suggesting a health concern related to the consumption of shellfish contaminated with PnTXs from Mediterranean lagoons, and particularly from the Ingril area. There is currently no shellfish production intended for sale from Ingril area. Nevertheless, ANSES highlighted the need to avoid all consumption of shellfish from this area. ANSES recommends that PnTXs should be taken into account in the French official monitoring of shellfish production areas.

The risk assessment underlying this conclusion is based on a worst-case scenario for estimating exposure to PnTX G, using the 95th percentile of shellfish contamination. A more realistic risk assessment could be conducted using a probabilistic approach (taking into account the distribution of all the data, on both contamination and consumption), which would require the acquisition of more contamination data in shellfish, particularly oysters (Anses, 2019). 


\section{Data gaps}

502 ANSES recommends undertaking research to estimate more accurately the exposure of shellfish consumers. More data on shellfish contamination by PnTXs are needed, including other species than

504

505

506

507

508

509

510

511

512

513

514

515

516

517

518

519

520

521

522

523

524

525

526 mussels and clams. More research is also needed to better characterize the oral toxicity of toxins produced by $V$. rugosum. As portimine is produced in large quantities by Mediterranean strains of Vulcanodinium rugosum, this toxin should be also considered. This toxin only seems to accumulate at very low levels in shellfish. Additional data are required to confirm its low accumulation in shellfish. Although less toxic than PnTXs in mice by the intraperitoneal route, the toxicological data for portimine are limited and investigation should be carried on. Three of the identified PtTXs (A to C) are structural analogues belonging to the PnTX group but, due to the lack of data available in the literature, they could not be taken into account in this risk assessment. More toxicity and contamination studies are needed.

An extensive acute oral toxicity study on PnTX G in rodents is needed (including description of clinical symptoms, assessment of biological, hematological and anatomopathological parameters as in the repeated dose studies, for a range of doses close to the maximum tolerated dose in the 2014 ANSESUniversity of Trieste-CNRS report study/Sosa et al., 2020), with a 14-day observation period.

A 28-day repeated oral administration study (OECD guideline 407) or even a 90-day study (OECD guideline 408) should be conducted. Given the data currently available, the effects on the central and peripheral nervous system as well as on the cardiovascular system should be investigated. Conducting a neurotoxicity study according to OECD guideline 424 is recommended.Preliminary results on in ovo exposure of chickens (Couesnon et al., 2014; unpublished results) suggest that PnTXs could affect embryonal growth. Therefore, the effects of PnTXs on offspring should be investigated, according to the OECD guideline 422. 
Conflicts of Interest: The authors declare no conflict of interest. The authors' declarations of interests are made public via the ANSES website (www.anses.fr).

\section{References}

532

533

534

535

536

537

538

539

540

541

542

543

544

545

546

547

548

549

550

551

552

553

554

555

556

Abadie, E., A. Muguet, T. Berteaux, N. Chomerat, P. Hess, E. Roque D'OrbCastel, E. Masseret, M.

Laabir, 2016. Toxin and Growth Responses of the Neurotoxic Dinoflagellate Vulcanodinium

rugosum to Varying Temperature and Salinity. Toxins 8(5). doi: 10.3390/toxins8050136.

Abadie, E., C. Chiantella, A. Crottier, L. Rhodes, E. Masseret, T. Berteaux, M. Laabir, 2018. What are the main environmental factors driving the development of the neurotoxic dinoflagellate Vulcanodinium rugosum in a Mediterranean ecosystem (Ingril lagoon, France)? Harmful Algae 75:75-86. doi:10.1016/j.hal.2018.03.012.

Al Muftah, A., A.I. Selwood, A.J. Foss, H.M. Al-Jabri, M. Potts, M. Yilmaz, 2016. Algal toxins and producers in the marine waters of Qatar, Arabian Gulf. Toxicon 122:54-66.

Anses (Agence nationale de sécurité sanitaire de l'alimentation, de l'environnement et du travail), 2017.

Valeurs toxicologiques de référence. Guide d'élaboration de l'Anses (only in French).

https://www.anses.fr/fr/system/files/SUBSTANCES2017SA0016Ra.pdf

Anses (Agence nationale de sécurité sanitaire de l'alimentation, de l'environnement et du travail), 2019. Risques liés aux pinnatoxines dans les coquillages. Avis de l'Anses et Rapport d'expertise collective, $\quad$ Mars $2019 \quad-\quad$ Édition $\quad$ scientifique, $136 \quad$ p, https://www.anses.fr/fr/system/files/ERCA2016SA0013Ra.pdf (full report only in French).

Anses-Université de Trieste-CNRS, 2014. Pinnatoxines en lien avec l'espèce Vulcanodinium rugosum (II) Partie 2 : Etudes sur la toxicité des pinnatoxines et d'extraits de Vulcanodinium rugosum, 72p. https://archimer.ifremer.fr/doc/00285/39635/38127.pdf 
Araoz, R., D. Servent, J. Molgó, B.I. Iorga, C. Fruchart-Gaillard, E. Benoit, Z. Gu, C. Stivala. A. Zakarian. 2011, Total synthesis of pinnatoxins $A$ and $G$ and revision of the mode of action of pinnatoxin A. J. Am. Chem. Soc. 133:10499-10511.

Benoit, E., A. Couesnon, J. Lindovsky, B.I. Iorga, R. Araoz, D. Servent, .A. Zakarian, J. Molgó. 2019. Synthetic pinnatoxins $A$ and $G$ reversibly block mouse skeletal neuromuscular transmission In Vivo and In Vitro. Mar. Drugs 17(5). pii: E306. doi: 10.3390/md17050306.

Couesnon, A., J. Lindovsky, A. Zakarian, S. Creuzet, J. Molgó, 2014. Pinnatoxins block skeletal neuromuscular junction activity and affect embryo development. Toxicon 91:175-176. doi:10.1016/j.toxicon.2014.08.036.

Chou, T., T. Haino, M. Kuramoto, D. Uemura, 1996. Isolation and structure of pinnatoxin D, a new shellfish poison from the Okinawan bivalve Pinna muricata. Tetrahedron Letters 37(23): 4027-4030.

Delcourt, N., Lagrange, E., Abadie, E., Fessard, V., Frémy, J.-M., Vernoux, J.-P., Peyrat, M.-B., Maignien, T., Arnich, N., Molgó, J., Mattei, C., 2019. Pinnatoxins' deleterious effects on cholinergic networks: From experimental models to human health. Marine Drugs 17, Issue 7, Article number 425.

EFSA (European Food Safety Authority). 2010a. Scientific Opinion on marine biotoxins in shellfish Cyclic imines (spirolides, gymnodimines, pinnatoxins and pteriatoxins). EFSA Journal 8 (6):1628. doi: doi:10.2903/j.efsa.2010.1628.

EFSA (European Food Safety Authority). 2010b. Statement on further elaboration of the consumption figure of $400 \mathrm{~g}$ shellfish meat on the basis of new consumption data. EFSA Journal 8 (8):1706. doi:10.2903/j.efsa.2010.1706.

Garcia-Altares, M., A. Casanova, V. Bane, J. Diogene, A. Furey, P. de la Iglesia, 2014. Confirmation of pinnatoxins and spirolides in shellfish and passive samplers from Catalonia (Spain) by liquid chromatography coupled with triple quadrupole and high-resolution hybrid tandem mass spectrometry. Mar Drugs 12 (6):3706-32. doi: 10.3390/md12063706. 
Garrett, M. J., C. Puchulutegui, A. I. Selwood, J. L. Wolny. 2014. Identification of the harmful

590

591

592

593

594

595

596

597

598

599

600

601

602

603

604

605

606

607

608

609

610

611

612

613

614

615

616

617

dinoflagellate Vulcanodinium rugosum recovered from a ballast tank of a globally traveled ship in Port Tampa Bay, Florida, USA." Harmful Algae 39:202-209. doi: 10.1016/j.hal.2014.07.014.

Hellyer, S. D., A. I. Selwood, L. Rhodes, D. S. Kerr, 2013. Neuromuscular blocking activity of pinnatoxins

E, F and G. Toxicon 76:214-20. doi: 10.1016/j.toxicon.2013.10.009.

Hellyer, S.D., D. Indurthi, T. Balle, V. Runder-Varga, A.I. Selwood, J.D.Tyndall, M. Chebib, L. Rhodes, D.S. Kerr. 2015. Pinnatoxins E, F and G target multiple nicotinic receptor subtypes. J. Neurochem. 135:479-91. doi: 10.1111/jnc.13245.

Hernandez-Becerril, D. U., M. C. Rodriguez-Palacio, C. Lozano-Ramirez, 2013. Morphology and life stages of the potentially pinnatoxin-producing thecate dinoflagellate Vulcanodinium rugosum from the tropical Mexican Pacific. Botanica Marina 56 (5-6):535-540. doi: 10.1515/bot-2013-0079.

Ifremer (Institut français de recherche pour l'exploitation de la mer). 2012. P. Hess, F. Hervé, E. Abadie, V. Séchet, J. Molgó, Z. Amzil, V. Fessard. Pinnatoxines en lien avec l'espèce Vulcanodinium rugosum. Référence Ifremer: 11/1219401/NYF, 09-2012 - R.RBE/EMP/PHYC 12-05, 144 p. https://archimer.ifremer.fr/doc/00094/20518/18190.pdf

Klimisch, H. J., M. Andreae, U. Tillmann, 1997. A systematic approach for evaluating the quality of experimental toxicological and ecotoxicological data." Regul Toxicol Pharmacol 25 (1):1-5. doi:10.1006/rtph.1996.1076.

Lamas, J.P., Arévalo, F., Moroño, Á., Correa, J., Muñíz, S., Blanco, J. 2019. Detection and spatiotemporal distribution of pinnatoxins in shellfish from the Atlantic and Cantabrian coasts of Spain. Toxins 11(6). pii: E340. doi: 10.3390/toxins11060340. 
MacKenzie, L. A., A. I. Selwood, P. McNabb, L. Rhodes, 2011. Benthic dinoflagellate toxins in two warmtemperate estuaries: Rangaunu and Parengarenga Harbours, Northland, New Zealand. Harmful Algae 10 (6):559-566. doi: 10.1016/j.hal.2011.02.007 .

621

McCarron, P., W. A. Rourke, W. Hardstaff, B. Pooley, M. A. Quilliam, 2012. Identification of 623 pinnatoxins

624 and discovery of their fatty acid ester metabolites in mussels (Mytilus edulis) from eastern Canada. $\mathrm{J}$ Agric Food Chem 60 (6):1437-46. doi: 10.1021/jf204824s.

McCauley, J.A., K. Nagasawa, P.A., S.G. Mischke, M.A. Semones, Y. Kishi, 1998. Total synthesis of pinnatoxin A. J. Am. Chem. Soc. 120(30):7647-7648.

McNabb, P. S., D. J. McCoubrey, L. Rhodes, K. Smith, A. I. Selwood, R. van Ginkel, A. L. MacKenzie, R. Munday, P. T. Holland, 2012. New perspectives on biotoxin detection in Rangaunu Harbour, New Zealand arising from the discovery of pinnatoxins. Harmful Algae 13:34-39. doi:10.1016/j.hal.2011.09.013.

Molgó, J., P. Marchot, R. Aráoz, E. Benoit, B.I. lorga, A. Zakarian, P. Taylor, Y. Bourne, D. Servent. 2017. Cyclic imine toxins from dinoflagellates: a growing family of potent antagonists of the nicotinic acetylcholine receptors. J. Neurochem., 142 S2:41-51. doi: 10.1111/jnc.13995.

Moreira-Gonzalez, A.R., A. Comas-Gonzalez, A. Valle-Pombrol, M. Seisdedo-Losa, C. Alonsohernadez, O. Hernandez-Leyva, L.F. Ferandes, N. Chomerat, G. Bilien, F. Herve, G.A. Rovillon, P. Hess, L.L. Mafra, 2018. Summer bloom of Vulcanodinium rugosum in Cienfuegos Bay (Cuba) associated to dermatitis in swimmers. 18th edition of the International Conference on Harmful Algae (ICHA), 21- 26 October 2018, Nantes (France). Poster 238. Abstract book https://www.icha2018.com/medias/content/files/ICHA 2018 Abstract Book v8.pdf Munday, R., A. I. Selwood, L. Rhodes, 2012. Acute toxicity of pinnatoxins E, F and G to mice. Toxicon $60(6): 995-999$. 
Nézan, E., Chomérat, N., 2011. Vulcanodinium rugosum gen. nov., sp. nov. (dinophyceae): A new

Otero, P., Miguéns, N., Rodríguez, I., Botana, L.M. 2019. LC-MS/MS Analysis of the Emerging Toxin

Pinnatoxin-G and High Levels of Esterified OA Group Toxins in Galician Commercial Mussels. Toxins

655

Rambla-Alegre, M., C. O. Miles, P. de la Iglesia, M. Fernandez-Tejedor, S. Jacobs, I. Sioen, W. Verbeke, I. A. Samdal, M. Sandvik, V. Barbosa, A. Tediosi, E. Madorran, K. Granby, M. Kotterman, T.

Calis, J. Diogene, 2018. Occurrence of cyclic imines in European commercial seafood and consumers 659 risk

Rhodes, L., K. Smith, A. Selwood, P. McNabb, R. van Ginkel, P. Holland, R. Munday, 2010. Production of pinnatoxins by a peridinoid dinoflagellate isolated from Northland, New 664 Zealand."Harmful Algae 9(4):384-389. doi: 10.1016/j.hal.2010.01.008.

665

Rhodes, L., K. Smith, A. Selwood, P. McNabb, S. Molenaar, R. Munday, C. Wilkinson, G. Hallegraeff, 667 2011. Production of pinnatoxins E, F and G by scrippsielloid dinoflagellates isolated from Franklin 668 Harbour, South Australia. New Zealand Journal of Marine and Freshwater Research 45 (4):703-709. doi: 10.1080/00288330.2011.586041.

670

Rundberget, T., J. A. Aasen, A. I. Selwood, C. O. Miles, 2011. Pinnatoxins and spirolides in Norwegian blue mussels and seawater. Toxicon 58 (8):700-11. doi: 10.1016/j.toxicon.2011.08.008.

673 
Selwood, A. I., A. L. Wilkins, R. Munday, F. Shi, L. L. Rhodes, P. T. Holland, 2013. Portimine: A bioactive metabolite from the benthic dinoflagellate Vulcanodinium rugosum. Tetrahedron Letters 54(35):4705-4707. doi: 10.1016/j.tetlet.2013.06.098.

Selwood, A. I., A. L. Wilkins, R. Munday, H. Gu, K. F. Smith, L. L. Rhodes, F. Rise, 2014. Pinnatoxin $\mathrm{H}$ :

A new pinnatoxin analogue from a South China Sea Vulcanodinium rugosum isolate. Tetrahedron Letters 55 (40):5508-5510. doi: 10.1016/j.tetlet.2014.08.056.

Smith, K. F., L. L. Rhodes, S. Suda, A. I. Selwood, 2011. A dinoflagellate producer of pinnatoxin G, isolated from sub-tropical Japanese waters." Harmful Algae 10 (6):702-705. doi:10.1016/j.hal.2011.05.006.

Sosa, S., Pelin, M., Cavion, F., Hervé, F., Hess, P., Tubaro, A. 2020. Acute oral toxicity of pinnatoxin G in mice. Toxins (Basel). 2020 Jan 28;12(2). pii: E87. doi: 10.3390/toxins12020087.

Takada, N., N. Umemura, K. Suenaga, D. Uemura, 2001. Structural determination of pteriatoxins A, B and C, extremely potent toxins from the bivalve Pteria penguin. Tetrahedron Letters 42 (20):34953497. doi: 10.1016/S0040-4039(01)00478-6.

Uemura, D., T. Chou, T. Haino, A. Nagatsu, S. Fukuzawa, S. Z. Zheng, H. S. Chen, 1995. Pinnatoxina -a toxic amphoteric macrocycle from the Okinawan bivalve Pinna muricata. J Am Chem Soc 117(3):1155-1156. doi: 10.1021/ja00108a043.

Zendong, Z., C. Herrenknecht, E. Abadie, C. Brissard, C. Tixier, F. Mondeguer, V. Sechet, Z. Amzil, P. Hess. 2014. Extended evaluation of polymeric and lipophilic sorbents for passive sampling of marine toxins. Toxicon 91:57-68. doi: 10.1016/j.toxicon.2014.03.010.

Zeng, N., H. Gu, K. F. Smith, L. L. Rhodes, A. I. Selwood, W. Yang, 2012. The first report of Vulcanodinium rugosum (Dinophyceae) from the South China Sea with a focus on the life cycle. New 


\section{Journal Pre-proof}

(4):511-521.

709 doi:10.1080/00288330.2012.719911. 


\section{HIGHLIGHTS}

- A state of knowledge of PnTXs and Vulcanodinium rugosum is proposed.

- A provisional acute health-based guidance value for PnTX G of $0.13 \mu \mathrm{g} / \mathrm{kg}$ bw per day has been derived.

- PnTXs in shellfish should not exceed $23 \mu \mathrm{g}$ PnTX G/kg.

- PnTXs should be included in national official monitoring programs for shellfish production.

- This work is a major step forward in taking into account this emerging hazard. 
No need for our manuscript 


\section{Declaration of interests}

$\bigotimes$ The authors declare that they have no known competing financial interests or personal relationships that could have appeared to influence the work reported in this paper.

$\square$ The authors declare the following financial interests/personal relationships which may be considered as potential competing interests: 